Serviço de Patologia e Clínicas Cirúrgica e Obstétrica

Prof. Dr. R. Straunard

\title{
HÉRNIA INGUINAL BILATERAL EM CADELA ENTEROCISTOCELE (*)
}

\author{
S. N. Piratininga \\ Assistente \\ 1 estampa (2 figuras)
}

Em Janeiro de 1941 foi operada, com inteiro sucesso, uma cachorra de 12 anos, que se apresentava com uma hérnia inguinal bilateral (Figura 1).

O processo herniário, pouco notável em seu início, um ano antes, não provoca distúrbios; lenta e progressivamente, porém, aumenta o volume das regiões inguinais e, finalmente, os sintomas se mostram evidentes : o animal se torna triste, deixa de conier; a defecação é rara e escassa; a micção dificil, gota a gota; a quantidade de urina diminue e o aspecto é sanguinolento.

Temperatura retal baixa, $37^{\circ}, 6$; pulso fraco, acelerado, em número de 128 pulsações por minuto; 28 movimentos respiratórios na unidade de tempo.

O tumor do lado direito é mais volumoso. Sensivel à palpação, apresenta consistência semi-flutuante; percebe-se, porém, no centro de sua massa, um corpo quasi duro, em forma de pera. As tentativas de redução não dão resultado.

O tumor do lado esquerdo é de consistência mole, indolor e fàcilmente redutivel; o seu tamanho corresponde à metade do outro, mais ou menos.

A vulva se mostra tumefata, edemaciada.

Pelo toque retal nenhum órgão se alcança à entrada da bacia.

Não é possivel o cateterismo: a sonda não penetra além de 2 cms. e provoca emissão de algumas gotas de urina sanguinolenta.

$\mathrm{O}$ diagnóstico de hérnia inguinal bilateral é evidente. Os resultados da exploração retal e cateterismo, unidos aos dados obtidos pela palpação, permitem estabelecer a bexiga como parte integrante do conteúdo herniário direito.

Com anestesia geral por inalação, pelo balsofórmio, pratica-se a intervenção cirúrgica. Após incisão da pele na linha mediana, justificada pela contiguidade das hérnias, isola-se primeiramente o saco herniário direito; feita a abertura deste, eliminando-se antes por punção e aspiração o seu conteúdo liquido (150 c.c. de transudato

(*) Comunicado à Sociedade Paulista de Medicina Veterinaria em 2-6-1941. 
hemorrágico), verificam-se os órgãos herniados (várias alças intestinais congestas; bexiga em congestão passiva acentuada, de coloração vermelho-escura, quasi preta no apice - Figura 2); alarga-se com uma incisão o anel para possibilitar a redução; efetuada esta, faz-se a ablação do saco e fecha-se o orifício herniário com pontos separados de catgut. A seguir, pratica-se o isolamento do saco esquerdo, redução da hérnia, ligadura do saco proxima ao colo, excisão da parte excedente e sepultamento do côto com sutura da muscular. Finalmente, sutura da pele com agrafes.

O post-operatório decorre de modo satisfatório: melhora progressiva do estado geral, a hematúria desaparece pouco a pouco, a evacuação se normalisa. No sétimo dia depois da operação os agrafes são retirados, apresentando-se o animal com $38^{\circ}, 4$ de temperatura e pulso cheio, forte, com 100 pulsações por minuto.

A hérnia inguinal da cadela não constitue raridade. A localisação da bexiga no conteúdo herniário, nas condições observadas, e o resultado cirúrgico, tratando-se de uma cachorra de 12 anos, constituem os motivos para a apresentação dêste caso.

\section{$S u m m a r y$}

The author describes an operation performed on a 12 years old bitch, suffering from bilateral inguinal hernia. The right hernia contained, besides part of the intestinal tract, the bladder showing a pronounced passive congestion. The animal was completely cured.

\section{EXPLICAÇÃO DAS FIGURAS}

Figura 1 - Vista ventral do animal portador da hérnia inguinal bilateral.

Figura 2 - Campo operatório aparecendo o conteúdo herniário direito: alças intestinais e (B) bexiga. 
S. N. Piratininga,

Hérnia inguinal bilateral em cadela

Rev. Fac. Med. Vet. S. Paulo, Vol, 2, fasc. $s$

Estampa 1

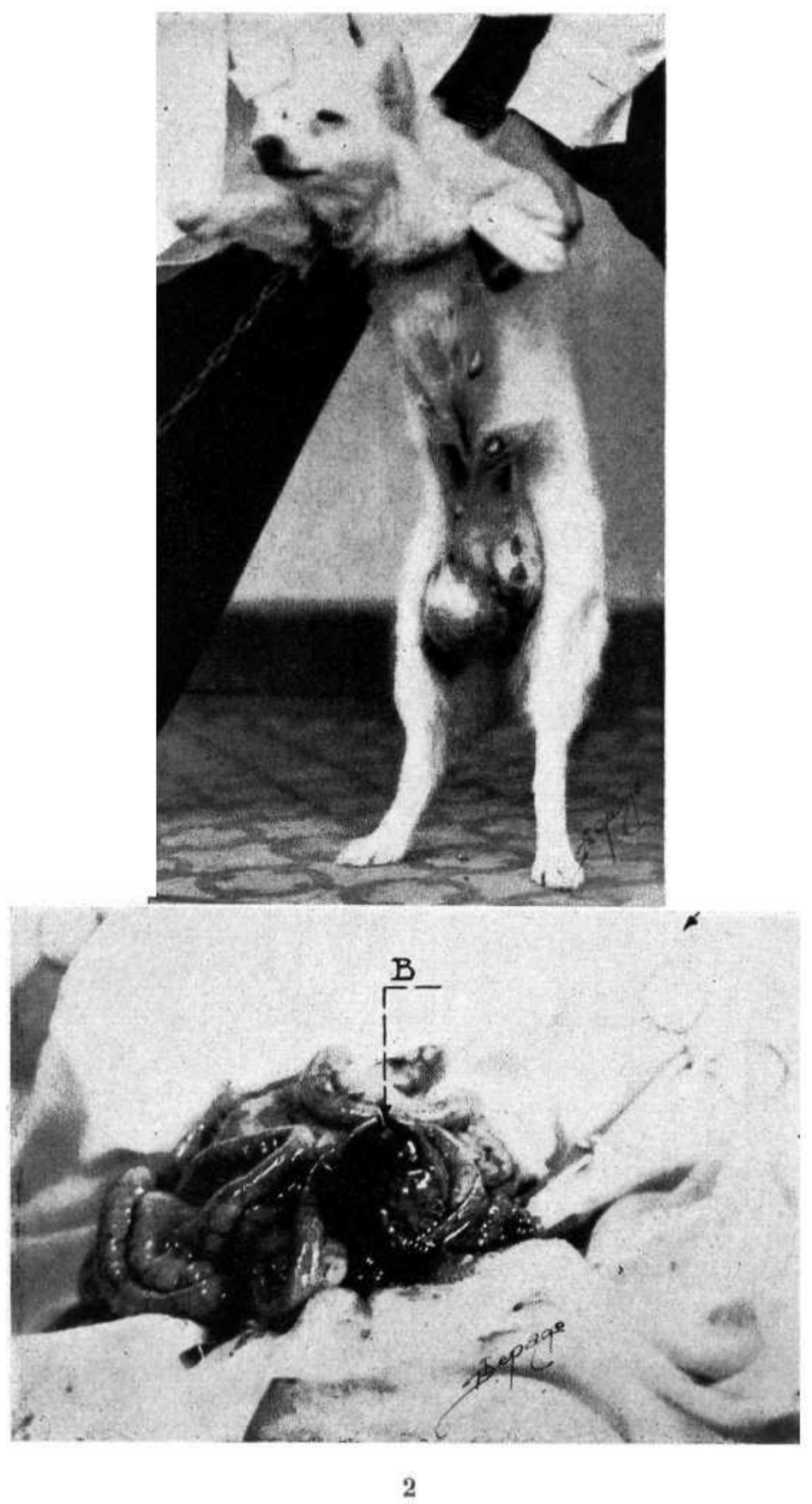

